\title{
Blood lead, ethnic origin, and lead exposure
}

\author{
G M SINGAL, ${ }^{*}$ A R GATRAD,$\dagger$ P M HOWSE, $\dagger \mathrm{K}$ W JOHNSON, $\uparrow$ M GANLEY, $\ddagger$ \\ A THOMAS, $\ddagger$ R A BRAITHWAITE, $\S$ AND S S BROWN§
}

${ }^{*}$ Walsall District Health Authority, †Department of Paediatrics, Walsall Manor Hospital, ¥Information Department, West Midlands Regional Health Authority, and \$West Midlands Regional Laboratory for Toxicology, Dudley Road Hospital, Birmingham

SUMMARY A survey of blood lead concentrations is reported in a group of 199 young Walsall children (3-6 years of age). The geometric mean blood lead concentration was $0.47 \mu \mathrm{mol} / 1$ (range $0.2-1.6 \mu \mathrm{mol} / \mathrm{l}$ ). There were no significant differences in blood lead concentrations between groups of children with different ages, sex, ethnic origin, or environment.

Environmental lead pollution is widely regarded as a risk to child health. Raised blood lead concentrations in children, however, can be due to many causes including airborne lead, lead in soil, lead in household dust, pica, finger sucking, lead in food and water supplies, and lead in oriental cosmetics (for example, surma).

Walsall is an industrial borough with established atmospheric and soil lead pollution. Earlier surveys carried out in Birmingham reported that many inner city children (particularly of the ethnic Asian minority) had raised blood lead concentrations $(>1.69 \mu \mathrm{mol} / \mathrm{l}) .^{12}$ The main objective of the present collaborative study was to carry out a pilot survey of blood lead concentrations in young Walsall children and to assess factors that might be expected to influence blood lead concentrations-for example, age, sex, ethnic origin, location of home, diet, and social background.

\section{Subjects and methods}

The study population comprised 199 children randomly selected from the Walsall Child Health Register stratified by age, sex, ethnic state, and area of residence. Children aged 3-6 years were from three 'lead polluted' areas and one 'control' area of Walsall (table). A questionnaire covering relevant social and environmental information was completed by a health visitor in the home, along with a hand wipe test for lead. A clinical examination for growth parameters and for signs of lead intoxication was carried out together with a venepuncture for blood lead, haemoglobin, and zinc protoporphyrin concentrations.

Blood lead concentrations were measured by atomic absorption spectrometry (Delves' cup). Particular attention was paid to ensuring good accuracy and precision. ${ }^{3}$ Measurement of hand lead was carried out with lead free moist tissues used for personal cleansing. Two other tests were selected as potential markers of chronic lead exposure-blood haemoglobin and erythrocyte zinc protoporphyrin.

\section{Results}

The frequency distribution of blood lead concentrations for the whole population (figure) shows a distinct positive 'skew', consistent with a log-normal distribution. The geometric mean was $0.47 \mu \mathrm{mol} / \mathrm{l}$, with extreme values of 0.2 and $1.6 \mu \mathrm{mol} / \mathrm{l}$. There were no significant differences in blood lead concentrations for children living in the four geographic areas (table). Moreover, age, sex, and ethnic origin did not significantly influence blood lead concentrations. Only five children from the ethnic minority used surma eye make up and this factor did not significantly influence blood lead concentrations.

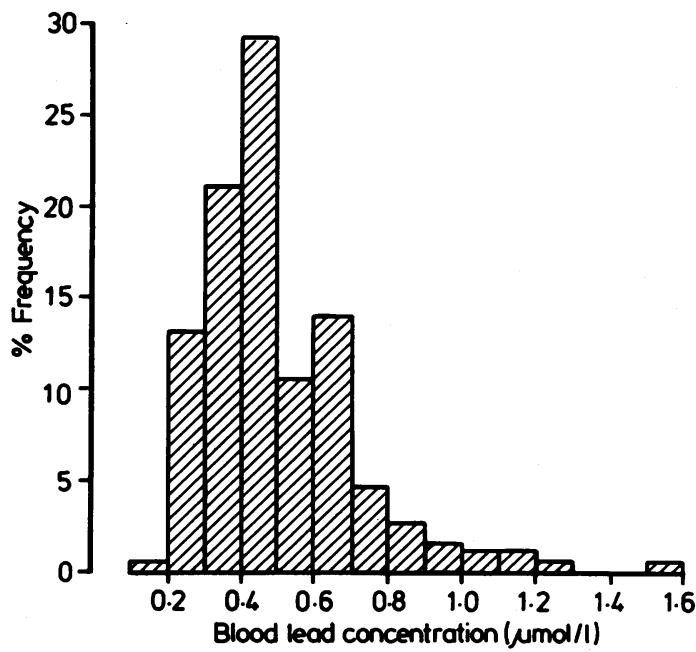

Figure Histogram of the percentage frequency distribution of blood lead concentrations in Walsall children $(n=199)$. Each interval corresponds to 0.1 umolll. 
Table Characteristics of sample population and geometric mean value for blood lead, haemoglobin, zinc protoporphyrin, and hand lead for children living in different locations

\begin{tabular}{|c|c|c|c|c|c|c|c|c|}
\hline \multirow[t]{2}{*}{ Location } & \multirow[t]{2}{*}{$\operatorname{Sex}$} & \multicolumn{3}{|c|}{ No of children } & \multicolumn{3}{|c|}{ Blood concentrations (geometric mean) } & \multirow{2}{*}{$\begin{array}{l}\text { Concentration } \\
\text { of hand lead } \\
\text { (geometric } \\
\text { mean) } \\
(\mu g)\end{array}$} \\
\hline & & White & $\begin{array}{l}\text { Ethnic } \\
\text { minority }\end{array}$ & Total & $\begin{array}{l}\text { Lead } \\
\text { (umol/l) }\end{array}$ & $\begin{array}{l}\text { Haemoglobin } \\
(\mathrm{g} / \mathrm{l})\end{array}$ & $\begin{array}{l}\text { Erythrocyte zinc } \\
\text { protoporphyrin } \\
(\mathrm{mg} / \mathrm{l})\end{array}$ & \\
\hline $\begin{array}{l}\text { Area } 1 \text { (high air } \\
\text { and soil lead) }\end{array}$ & $\begin{array}{l}\mathbf{M} \\
\mathbf{F}\end{array}$ & $\begin{array}{l}10 \\
12\end{array}$ & $\begin{array}{l}15 \\
13\end{array}$ & $\begin{array}{l}25 \\
25\end{array}$ & $0 \cdot 45$ & 119 & $0 \cdot 29$ & $5 \cdot 8$ \\
\hline $\begin{array}{l}\text { Area } 2 \text { (high air } \\
\text { lead) }\end{array}$ & $\begin{array}{l}\mathrm{M} \\
\mathrm{F}\end{array}$ & $\begin{array}{l}10 \\
17\end{array}$ & $\begin{array}{r}9 \\
13\end{array}$ & $\begin{array}{l}19 \\
30\end{array}$ & $0 \cdot 48$ & 116 & $0 \cdot 26$ & $7 \cdot 6^{*}$ \\
\hline $\begin{array}{l}\text { Area } 3 \text { (high } \\
\text { soil lead }\end{array}$ & $\begin{array}{l}\mathrm{M} \\
\mathrm{F}\end{array}$ & $\begin{array}{l}15 \\
12\end{array}$ & - & $\begin{array}{l}15 \\
12\end{array}$ & $0 \cdot 43$ & 127 & $0 \cdot 26$ & $4 \cdot 5^{*}$ \\
\hline $\begin{array}{l}\text { Area } 4 \text { (control area: } \\
\text { low air and soil lead) }\end{array}$ & $\begin{array}{l}\mathrm{M} \\
\mathrm{F}\end{array}$ & $\begin{array}{l}21 \\
19\end{array}$ & $\begin{array}{l}16 \\
17\end{array}$ & $\begin{array}{l}37 \\
36\end{array}$ & 0.49 & 120 & $0 \cdot 29$ & $5 \cdot 3$ \\
\hline Total (range) & $\begin{array}{l}\mathrm{M} \\
\mathrm{F}\end{array}$ & $\begin{array}{l}56 \\
60\end{array}$ & $\begin{array}{l}40 \\
43\end{array}$ & $\begin{array}{r}96 \\
103\end{array}$ & $0.47(0 \cdot 2-1 \cdot 6)$ & $125(80-170)$ & $0 \cdot 28(0 \cdot 13-1 \cdot 8)$ & $6 \cdot 1(2-198)$ \\
\hline
\end{tabular}

*Significant $(\mathrm{p}<0 \cdot 05)$ difference in hand lead concentrations in these two areas.

Hand wipe measurements as a marker for lead exposure were carried out in 194 children. Hand wipe lead in white children was significantly higher $(t=2.33, p<0.05)$ compared with the ethnic minority group.

Measurement of erythrocyte zinc protoporphyrin in 199 children showed no correlation with blood lead concentrations $(r=0 \cdot 02)$. Moreover, there were no significant differences in erythrocyte zinc protoporphyrin concentrations in children from the four study areas (table). The only positive finding was an association between raised erythrocyte zinc protoporphyrin concentrations and significant iron deficiency anaemia.

The geometric mean blood haemoglobin concentration was $125 \mathrm{~g} / \mathrm{l}$, with extreme values of 80 and $170 \mathrm{~g} / \mathrm{l}$. Eighteen children $(9 \%)$ had haemoglobin concentrations less than $110 \mathrm{~g} / \mathrm{l}$ and were regarded as being anaemic. There was no significant correlation between haemoglobin and blood lead concentrations $(r=0 \cdot 10)$. There were also no significant differences in mean haemoglobin concentrations for children living in the four study areas (table). There was, however, a highly significant negative correlation $(\mathrm{r}=-0 \cdot 65, \mathrm{p}<0 \cdot 01)$ between blood haemoglobin and erythrocyte zinc protoporphyrin concentrations. The plasma ferritin concentrations in children .with anaemia were all less than $10 \mu \mathrm{g} / \mathrm{l}$ (normal range $15-140 \mu \mathrm{g} / \mathrm{l}$ ). No children were found with either haemoglobinopathy or parasitic infection.

Clinical examination of all the children did not show any symptomatology suggestive of lead toxicity. There was no history of pica in any child. The height/weight statistics of the white children in the study fell within the expected range for European children. Although some children from the ethnic minority group were, as expected, below the third centile for both weight and height, there was no evidence of growth pathology.

\section{Discussion}

The main finding of this survey of blood lead concentrations in stratified populations of Walsall children was that the actual concentrations were surprisingly low. Moreover there were no significant differences in mean blood lead concentrations for groups of children of different age, sex, ethnic origin, or area of residence. Hand lead measurements were unhelpful in identifying children with relatively high blood lead concentrations. The present findings, therefore, are consistent with some recent and well conducted studies of blood lead concentrations in children living in other parts of the United Kingdom ${ }^{45}$ and well within current European Economic Community and Department of Health and Social Security guidelines, but they are at variance with earlier surveys carried out on preschool children in Birmingham. ${ }^{12}$ The present findings for concentrations of erythrocyte zinc protoporphyrin question the usefulness of this assay as a screening test for lead exposure.

The principal conclusion is that blood lead concentrations in Walsall children are relatively 'low', even in children living in relatively 'polluted' areas. If the values are representative of the population at large, they reflect very little risk to the health of children in Walsall. From the clinical examinations carried out on the children, there were no obvious physical or behavioural problems that could be related to lead exposure. The possibility of there being subtle deleterious effects of 'low level' lead 
exposure on child behaviour or intelligence could not be ruled out by the present study, but these effects, if real, are tiny compared with other factors which influence childrens' physical and mental development. ${ }^{6}$

We express our appreciation to the families of Walsall and their general practitioners, who allowed us to study the children, and to the health visitors based at Walsall Manor Hospital who carried out the field work for the survey. We also thank staff of the department of clinical chemistry, Walsall Manor Hospital and the department of haematology, Dudley Road Hospital, Birmingham for carrying out additional investigations.

\footnotetext{
References

1 Archer A, Giltrow JP, Waldron HA. Blood lead concentrations in pre-school children in Birmingham. $J R$ Soc Med 1980;73: 328-32.

2 Department of the Environment Central Directorate on En-
}

vironmental Pollution. Blood lead concentrations in pre-school children in Birmingham-Pollution Report No. 15. London: HMSO, 1982.

3 Braithwaite RA. Interlaboratory and intralaboratory surveys and reference methods. In: Stocppler M. ed. Trace metal analysis in biological specimens. California: Biomedical Publications, 1988 (in press)

+ Sherlock JC, Barltrop D, Evans WH, Quinn MJ, Smart GA, Strehlow C. Blood lead concentrations and lead intake in children of different ethnic origin. Hum Toxicol 1985:4:513-9.

5 Gallacher JEJ, Elwood PC, Phillips KM, Davies BE, Jones DT. Relationship between pica and blood lead in areas of differing lead exposure. Arch Dis Child 1984;59:40-4.

' Smith M. Intellectual and behavioural consequences of low level lead exposure: A revicw of recent studics. In: Taylor A, ed. Clinics in endocrinology and metabolism-trace elements in human disease. London: WB Saunders, 1985;14:657-80.

Correspondence to Dr RA Braithwaite, Regional Laboratory for Toxicology, Dudlcy Road Hospital, Birmingham B18 7QH.

Accepted 28 January 1988

\title{
Sublingual nifedipine in acute severe hypertension
}

\author{
J H C EVANS, N J SHAW, AND J T BROCKLEBANK \\ Department of Paediatrics and Child Health, St James's University Hospital, Leeds
}

SUMMARY Sublingual nifedipine was used for the treatment of acute severe hypertension in 12 children with renal disease. An average dose of 0.24 $\mathrm{mg} / \mathrm{kg}$ was safe and proved effective on most occasions within 30 minutes with a median duration of action of three hours. There were no major adverse effects.

The current recommendations for the treatment of hypertensive crises in children advocate the use of intravenous infusions of labetalol or sodium nitroprusside. ${ }^{1}$ Administration of these drugs has the disadvantage that they require parenteral administration and nitroprusside has to be protected from light to prevent decomposition. A drug that could be given orally that would act rapidly but would not cause profound hypotension would be an advantage. Nifedipine administered sublingually has been shown to be a safe and effective means of lowering blood pressure in adults. ${ }^{2}{ }^{3}$ Its advantages are the ease of administration, absence of serious side effects, and the fact that it has been shown to increase cerebral blood flow thus reducing the risk of cerebral ischaemia. ${ }^{2}$

Over an 18 month period from February 1986 we have collected data on the use of nifedipine on 35 occasions in 12 children with severe hypertension.

\section{Patients and methods}

The 12 children with known renal disorders were all studied while inpatients (table 1). Their ages ranged from 6-15 years and weights from $16-60 \mathrm{~kg}$. Eleven of the children were being treated with other antihypertensive drugs. Each child had an acute rise in blood pressure recorded on at least two occasions before treatment and needed urgent treatment. In each case the diastolic blood pressure was equal to or greater than $110 \mathrm{~mm} \mathrm{Hg}$. Children with features of hypertensive encephalopathy were not studied. Children below $30 \mathrm{~kg}$ body weight were given $5 \mathrm{mg}$ nifedipine and children weighing $30 \mathrm{~kg}$ or more $10 \mathrm{mg}$. The dose range was 0.18 to $0.32 \mathrm{mg} / \mathrm{kg}$ with a mean dose of $0.24 \mathrm{mg} / \mathrm{kg}$. The capsule was administered either by being cracked between the teeth and held under the tongue or by initially piercing the capsule with a needle and squeezing the contents out under the tongue. The blood pressure and pulse were measured before treatment, at 15 and 30 minutes, and then hourly for six hours. The blood pressure was measured with the child lying down by either one observer using a sphygmomanometer and an appropriate sized cuff covering at least two thirds of the upper arm, or an automated oscillometric device (Dinamap) when more than one observer monitored the blood pressure.

During the study period all other antihypertensive 